\title{
Effect of Shatavari Root Powder (Asparagus racemosus) Supplementation on Milk Composition of Sahiwal Crossbred Cows
}

\author{
Hitesh Muwal ${ }^{1 *}$, D.C. Rai ${ }^{1}$, Vinod Bhateshwar ${ }^{1}$, Jagdish Prasad Meena ${ }^{2}$ and Dwarki Lal ${ }^{1}$ \\ ${ }^{1}$ Department of Animal Husbandry and Dairying, Banaras Hindu University, Varanasi, Uttar Pradesh, INDIA \\ ${ }^{2}$ Subject Matter Specialist, Krishi Vigyan Kendra, Vadodara, Gujarat, INDIA \\ "Corresponding author: H Muwal; E-mail: hiteshmuwal230@gmail.com
}

Received: 15 Feb., 2020

Revised: 20 April, 2020

Accepted: 22 April, 2020

\begin{abstract}
The present investigation was conducted to assess the effect of Shatavari root powder (Asparagus racemosus) supplementation on milk composition of Sahiwal crossbred cows during summer season on twenty lactating Sahiwal crossbred (H.F. $\times$ Sahiwal) cows in early stage of lactation were selected for the experiment. All the cows were randomly divided into two groups $\mathrm{T}_{1}$ (control) and $\mathrm{T}_{2}$ (Treatment) of 10 in each group. The treatment group was provided Shatavari root powder @ $50 \mathrm{~g} / \mathrm{head} / \mathrm{day}$ for 90 days post partum. Data related to milk composition takes fortnightly interval. The overall average milk fat, Protein and Lactose percent during the experimental period in $\mathrm{T}_{1}$ and $\mathrm{T}_{2}$ groups were $3.77 \pm 0.01,3.84 \pm 0.03,3.43 \pm 0.01$ and $3.46 \pm 0.01$, $4.54 \pm 0.06$ and $4.69 \pm 0.06$ percent respectively, there was no significant $(\mathrm{P}<0.05)$ differences between $\mathrm{T}_{1}$ and $\mathrm{T}_{2}$ groups. The overall average solid not fat (values) and total solid (values) differed significantly $(\mathrm{P}<0.05)$ between $\mathrm{T}_{1}$ and $\mathrm{T}_{2}$ groups $8.84 \pm$ $0.04,9.11 \pm 0.11,12.66 \pm 0.03$ and $13.02 \pm 0.14 \%$ in $\mathrm{T}_{1}$ and $\mathrm{T}_{2}$ groups was significantly $(\mathrm{P}<0.05)$.
\end{abstract}

Keywords: Milk composition, Sahiwal crossbred cow, Shatavari root powder

The ancient history of India is very rich in herbal medicine. Ayurveda, one of the oldest surviving systems of health care in the world is totally based on herbs. There are several herbs which have been described in the Ayurveda to improve the general well beings, milk production and reproduction of both human and animals. Among them, Shatavari (Asparagus racemosus) needs a special mention. Ayurveda described that Shatavari overcomes all reproduction related complications and improves overall physiological system so called pillars of health including digestion, energy metabolism, immune and reproductive system. Shatavari is a creeper grown in all the tropical countries which is an important medicinal plant of tropical and subtropical India since prehistoric times. The genus Asparagus includes about 300 species around the world. Out of these, 22 species of Asparagus are found in India; In Sanskrit, the meaning of Shatavari is described as able to have one hundred husbands' and in Ayurveda this amazing herb is known as the "queen of herbs".
Shatavari (Asparagus racemosus) is one of the most commonly used in traditional medicine because of the presence of steroidal saponins and sapogenins in various parts of the plant (Krishna et al., 2005). Presence of more than 50 organic chemical compounds has been reported (Thomsen, 2007). Steroidal Saponins, Glycosides, Alkaloids, Polysaccharides, Mucilage, Flavones and Isoflavones are the few to be mentioned having medicinal properties. Shatavari (Asparagus racemosus) have various medicinal properties namely, Galactagogue and Mammogenic (Pandey et al., 2005)

Choudhary and Kar (1992) recorded that Shatavari root is rich source of minerals and it contains macro minerals such as calcium, magnesium, potassium and iron having

How to cite this article: Muwal, H., Rai, D.C., Bhateshwar, V., Meena, J.P. and Lal, D. (2020). Effect of Shatavari root powder (Asparagus racemosus) supplementation on milk composition of Sahiwal crossbred cows. J. Anim. Res., 10(3): 411-415.

Source of Support: None; Conflict of Interest: None क्ष 
concentration of $0.22,0.40,2.50$ and $0.01 \mathrm{~g} / 100 \mathrm{~g}$, respectively and micro minerals such as copper, zinc, manganese, cobalt and Chromium having concentration of 5.29, 53.15, 19.98, 22.0 and $1.8 \mu \mathrm{g} / \mathrm{gm}$, respectively. Berhane and Singh (2000) reported the dry matter, crude protein, ether extract, crude fibre, ash and nitrogen free extract of Shatavari root powder to be 91.0, 3.85, 0.66, 8.32, 13.15 and 74.02 percent, respectively. Mishra et al., (2005) reported that nutraceutical composition of Shatavari grown on partially reclaimedsodic soil root contains 4.60 to 6.10 percent protein, 36.80 to 47.50 percent carbohydrates, 3.10 to $5.20 \mathrm{mg} / \mathrm{g}$ phenols, 4.80 to $5.10 \mathrm{mg} / \mathrm{g}$ tannins, 4.10 percent saponin and 6.50 to 7.40 percent ash.

\section{MATERIALS AND METHODS}

The present study was conducted on lactating Sahiwal crossbred cows reared at Gaushala Dairy Farm, Department of Animal Husbandry and Dairying, Institute of Agricultural Sciences, Banaras Hindu University, Varanasi, Uttar Pradesh during summer season. Twenty lactating Sahiwal crossbred (H. F. $\times$ Sahiwal) cows in early stage of lactation were selected for the experiment. At the end of acclimatisation period all the cows were randomly divided into two groups $\mathrm{T}_{1}$ (control) and $\mathrm{T}_{2}$ (Treatment) of 10 in each group on basis of nearest in their body weight, number of lactation and milk yield of average per day. The dietary treatments were formulated and offered to each group of animals randomly to following feed supplements/ treatments are given in Table 1.

Table 1: Feeding schedule of lactating Sahiwal crossbred cows

\begin{tabular}{ll}
\hline Feed and fodders & Quantity of feed and fodders \\
\hline Wheat straw & $\begin{array}{l}8.0 \mathrm{~kg} \text { offered and fed ad lib. } \\
2.0 \mathrm{~kg} \text { for maintenance ration/animal and } \\
\text { Concentrate } 1.0 \mathrm{~kg} / 2.5 \text { litre milk yield for production } \\
\text { mixture }\end{array}$ \\
$\begin{array}{l}\text { ration } \\
\text { Green fodder }\end{array}$ & $5.0 \mathrm{~kg} / \mathrm{head} / \mathrm{day}$ \\
$\begin{array}{l}\text { Shatavari root } \\
\text { powder }\end{array}$ & $\begin{array}{l}\text { @ } 50 \mathrm{~g} / \mathrm{head} / \mathrm{day} \text { was offered (offered only } \\
\text { treatment group) }\end{array}$ \\
\hline
\end{tabular}

Similar housing and managemental facilities were provided to all the groups. The experimental crossbred cows were kept individually tied day and night during experimental period in cattle shed. The animals were offered individual feeding. The floor area was paved with cement concrete duly corrugated to prevent the animal from slipping. The animals were washed daily before milking at day time when the sun light was clear. The shed was cleaned daily early in the morning. All crossbred cows were dewormed with suitable anthelmentics R-WORM bolus (herbal dewormer) 1 bolus each cows for removing parasitic load before the start of experiment.

For carrying out study on proportional milk composition samples of morning and evening milk were collected every 15 days intervals for the analysis of milk components viz. Fat, Protein, Lactose, Solid not fat and Total solids. Each time $100 \mathrm{ml}$ of milk sample was collected in sterile plastic bottle after cleaning and disinfecting of teats and discharging the first streams of foremilk. There were a total of seven sampling on each lactating cow during the period of 90 days post partum trial. Representative amount of each sample was used for estimation of milk components by ultrasonic milk analyzer (Eco Milk).

Table 2: Biochemical constituents in root of Shatavari (Asparagus racemosus)

\begin{tabular}{ll}
\hline Biochemical constituents & Shatavari \\
\hline Protein $(\%)$ & 6.10 \\
Carbohydrates $(\%)$ & 47.50 \\
Crude Fat $(\%)$ & - \\
Phenol $(\%)$ & 5.20 \\
Tannin $(\%)$ & 5.10 \\
Saponin $(\%)$ & 4.10 \\
Total Ash $(\%)$ & 13.15 \\
Calcium $(\mathrm{g} / 100 \mathrm{~g})$ & 0.22 \\
Magnesium $(\mathrm{g} / 100 \mathrm{~g})$ & 0.40 \\
Potassium $(\mathrm{g} / 100 \mathrm{~g})$ & 2.50 \\
Iron $(\mathrm{g} / 100 \mathrm{~g})$ & 0.01 \\
Copper $(\mu / \mathrm{gm})$ & 5.29 \\
Zinc $(\mu / \mathrm{gm})$ & 53.15 \\
Manganese $(\mu / \mathrm{gm})$ & 19.98 \\
Cobalt $(\mu / \mathrm{gm})$ & 22.00 \\
Chromium $(\mu / \mathrm{gm})$ & 1.81 \\
\hline
\end{tabular}

Source: Patel et al. (2016) 


\section{STATISTICAL ANALYSIS}

Data related to milk yield, milk composition and post partum estrus were statistically analyzed using the one-way analysis of variance (SPSS version 21.0) for completely randomized design. All statements of significant differences were based on 0.05 probability level. Significant differences among treatments, within the experiment, were analyzed using the SPSS statistical software program.

\section{RESULTS AND DISCUSSION}

\section{Milk fat}

The changes in the milk fat in $\mathrm{T}_{1}$ and $\mathrm{T}_{2}$ groups given in Table 3. The overall average milk fat percent during the experimental period in $\mathrm{T}_{1}$ and $\mathrm{T}_{2}$ groups were $3.77 \pm 0.01$ and $3.84 \pm 0.03 \%$ respectively. The milk fat percent did not differed significantly $(\mathrm{P}<0.05)$ but was numerically higher in $\mathrm{T}_{2}$ group. However, fat percent in Shatavari root powder supplemented (@50 g/head/day) $\mathrm{T}_{2}$ group was lower during first fortnight and higher at $5^{\text {th }}, 6^{\text {th }}$ and $7^{\text {th }}$ fortnight than the $T_{1}$ group. These values were similar to the earlier reports of milk fat content in lactating crossbred cows (Singh et al., 2012; Veena et al., 2013; Jain and Bais, 2016) levels of Shatavari supplemented milk fat content did not differ significantly $(\mathrm{P}>0.05)$ compared to control.

\section{Milk protein}

Protein is the most valuable component of milk and also the most consistent component of milk Table 3. The milk protein content percent did not differed significantly but was numerically higher in $\mathrm{T}_{2}$ group. The similar result also found by Dibya, (2010) that the effect of Shatavari root powder containing ration on milk protein percent $3.41,3.58,3.66,3.77$ and $3.67 \%$ in $\mathrm{T}_{1}, \mathrm{~T}_{2}, \mathrm{~T}_{3}, \mathrm{~T}_{4}$ and $\mathrm{T}_{5}$ respectively. Many researchers (Sharma, 2010; Galbat et al., 2014; Kumar et al., 2014) reported that herbal fed supplementation positively significant on milk protein was higher $(\mathrm{P}>0.05)$ in animals fed experimental additives than control.

\section{Milk lactose}

The average fortnightly milk lactose values in lactating Sahiwal crossbred cows is given in Table 3 . There were no significant $(\mathrm{P}<0.05)$ differences between $\mathrm{T}_{1}$ (control) and $T_{2}$ groups in lactose content of milk. However, value in $T_{2}$ group was numerically higher than the $T_{1}$ (control) group probably due to higher milk production in $\mathrm{T}_{2}$ group. The results were in agreement with (Dibya, 2010) reported the effect of Shatavari root powder containing ration on milk lactose 4.87, 4.78, 4.76,4.75 and $4.78 \%$ in $\mathrm{T}_{1}, \mathrm{~T}_{2}, \mathrm{~T}_{3}$, $\mathrm{T}_{4}$ and $\mathrm{T}_{5}$ respectively. The physicochemical analysis of milk lactose levels of Shatavari supplemented milk did not

Table 3: Fortnightly milk constituent indices of cows fed diets with and without Shatavari root powder.

\begin{tabular}{|c|c|c|c|c|c|c|c|c|}
\hline \multirow{2}{*}{ Treatment } & \multicolumn{7}{|c|}{ Days } & \multirow{2}{*}{ Overall mean } \\
\hline & $\mathbf{0}$ & 15 & 30 & 45 & 60 & 75 & 90 & \\
\hline \multicolumn{9}{|c|}{ Milk fat (\%) } \\
\hline T1 & $3.71 \pm 0.01$ & $3.73 \pm 0.02$ & $3.78 \pm 0.02$ & $3.75 \pm 0.02$ & $3.80 \pm 0.02$ & $3.85 \pm 0.02$ & $3.82 \pm 0.03$ & $3.77 \pm 0.01$ \\
\hline $\mathrm{T} 2$ & $3.74 \pm 0.02$ & $3.77 \pm 0.02$ & $3.83 \pm 0.03$ & $3.80 \pm 0.03$ & $3.87 \pm 0.02$ & $3.96 \pm 0.02$ & $3.92 \pm 0.03$ & $3.84 \pm 0.03$ \\
\hline \multicolumn{9}{|c|}{ Milk protein (\%) } \\
\hline $\mathrm{T} 1$ & $3.35 \pm 0.13$ & $3.42 \pm 0.03$ & $3.48 \pm 0.01$ & $3.47 \pm 0.01$ & $3.40 \pm 0.01$ & $3.43 \pm 0.01$ & $3.46 \pm 0.01$ & $3.43 \pm 0.01$ \\
\hline $\mathrm{T} 2$ & $3.40 \pm 0.02$ & $3.47 \pm 0.00$ & $3.44 \pm 0.05$ & $3.50 \pm 0.00$ & $3.44 \pm 0.01$ & $3.53 \pm 0.01$ & $3.50 \pm 0.00$ & $3.46 \pm 0.01$ \\
\hline \multicolumn{9}{|c|}{ Milk lactose (\%) } \\
\hline $\mathrm{T} 1$ & $4.31 \pm 0.03$ & $4.37 \pm 0.01$ & $4.47 \pm 0.03$ & $4.57 \pm 0.02$ & $4.62 \pm 0.04$ & $4.64 \pm 0.03$ & $4.80 \pm 0.02$ & $4.54 \pm 0.06$ \\
\hline $\mathrm{T} 2$ & $4.43 \pm 0.16$ & $4.48 \pm 0.05$ & $4.71 \pm 0.02$ & $4.78 \pm 0.01$ & $4.80 \pm 0.01$ & $4.80 \pm 0.02$ & $4.87 \pm 0.03$ & $4.69 \pm 0.06$ \\
\hline \multicolumn{9}{|c|}{ Milk solid not fat (\%) } \\
\hline T1 & $8.64 \pm 0.01$ & $8.77 \pm 0.04$ & $8.83 \pm 0.01$ & $8.87 \pm 0.01$ & $8.89 \pm 0.01$ & $8.92 \pm 0.01$ & $8.99 \pm 0.01$ & $8.84 \pm 0.04$ \\
\hline $\mathrm{T} 2$ & $8.68 \pm 0.00$ & $8.91 \pm 0.02$ & $8.97 \pm 0.02$ & $9.04 \pm 0.02$ & $9.25 \pm 0.01$ & $9.44 \pm 0.01$ & $9.54 \pm 0.02$ & $9.11 \pm 0.11$ \\
\hline \multicolumn{9}{|c|}{ Milk total solid (\%) } \\
\hline $\mathrm{T} 1$ & $12.49 \pm 0.00$ & $12.72 \pm 0.00$ & $12.80 \pm 0.01$ & $12.66 \pm 0.00$ & $12.61 \pm 0.00$ & $12.76 \pm 0.01$ & $12.64 \pm 0.01$ & $12.66 \pm 0.03$ \\
\hline $\mathrm{T} 2$ & $12.57 \pm 0.01$ & $12.82 \pm 0.01$ & $12.78 \pm 0.01$ & $12.88 \pm 0.02$ & $13.07 \pm 0.04$ & $13.35 \pm 0.01$ & $13.72 \pm 0.04$ & $13.02 \pm 0.14$ \\
\hline
\end{tabular}


differ significantly $(\mathrm{P}>0.05)$ compared to control (Veena et al., 2013).

\section{Milk solid not fat (SNF)}

The SNF percent content in the supplemented groups were higher from first fortnightly to seven fortnightly (Table $3)$, though statistically values was significantly $(\mathrm{P}<0.05)$ higher in $\mathrm{T}_{2}$ than the $\mathrm{T}_{1}$. SNF content varied within the fortnights $(\mathrm{P}<0.05)$ as $\mathrm{SNF}$ content in milk remain inversely equivalent to milk yield. Kumar et al. (2018) also found significantly effect of the herbal fed on the SNF percent in crossbred cows. The SNF percent of $\mathrm{T}_{0}$, $\mathrm{T}_{1}, \mathrm{~T}_{2}$ and $\mathrm{T}_{3}$ group of cows increased to $7.32 \pm 0.03,7.46$ $\pm 0.04,7.71 \pm 0.05$ and $7.84 \pm 0.04$ respectively. Cows fed Shatavari (Asparagus racemosus) root powder $40 \mathrm{gm}, 80$ gm and 120 gm found significantly milk solid not fat yield content $(\mathrm{P}<0.01)$ than control cows (Saini et al., 2018).

\section{Milk total solid (TS)}

The overall mean total solids percent content of milk was significantly $(\mathrm{P}<0.05)$ higher in $\mathrm{T}_{2}$ than the $\mathrm{T}_{1}$ group. The total solids percent of milk during the experimental period ranged between $12.49 \pm 0.00$ to $12.80 \pm 0.01$ and $12.57 \pm$ 0.01 to $13.72 \pm 0.04$ in $\mathrm{T}_{1}$ and $\mathrm{T}_{2}$ groups respectively during the fortnights after initiation of lactation. The results were in agreement with (Dibya, 2010) in lactating cows who reported the effect of shatavari root powder on total solid content was $12.46,12.63,12.78,13.08$ and 12.83 percent total solid for $\mathrm{T}_{1}, \mathrm{~T}_{2}, \mathrm{~T}_{3}, \mathrm{~T} 4$ and $\mathrm{T}_{5}$ respectively. Significant $(\mathrm{P}>0.05)$ difference was observed between the total solids content of Shatavari supplemented animals than control (Sharma, 2010, Veena et al., 2013, 2014; Kumar et al., 2014).

\section{CONCLUSION}

On the basis of the present investigation, it may be concluded that the milk composition (including fat, protein and lactose, percent) in lactating Sahiwal crossbred cows did not differed significantly $(\mathrm{P}<0.05)$ The SNF and TS content in the supplemented groups were higher from first fortnight to seven fortnight, though statistically values were significantly $(\mathrm{P}<0.05)$ higher in $\mathrm{T}_{2}$ than the $\mathrm{T}_{1}$. These results are only indicative and require further experimentation to arrive at some more consistent conclusion.

\section{REFERENCES}

Berhane, M. and Singh, V.P. 2000. Effect of feeding indigenous galactopoietic feed supplements on milk production in crossbred buffalos. Indian J. Anim. Sci., 72(7): 609-611.

Choudhary, B.K. and Kar, A. 1992. Mineral contents of Asparagus racemosus. Indian Drugs. 29: 623.

Dibya, K.K. 2010. Shatavari (Asparagus racemosus willd.) Used as a feed supplement for enhancing production and quality of indigenous cross breed cow's milk. M.Sc. Thesis, Indira Gandhi Krishi Vishwavidyalaya, Raipur, Chattisgarh, India.

Galbat, S.A., El-Shemy, A., Madpoli, A.M., Omayma, M.A.L., Maghraby and El-Mossalami, E.I. 2014. Effects of some medicinal plants mixture on milk performance and blood components of Egyptian dairy goats. Middle E. J. App. Sci., 4(4): 942-948.

Jain, M. and Bais, B. 2016. Effect of jiwanti (Leptadenia reticulata) supplementation on fat percentage and fat yield of milk produced by Kankrej cows in arid zone of Rajasthan, India. Research and Reviews. J. Vet. Sci., 2(1): 1-3.

Krishna, L., Swarup, D. and Patra, R.C. 2005. An overview of prospects of ethano-veterinary medicine in India.Indian $J$. Anim. Sci., 75(12): 1481-1491.

Kumar, S. and Kumar, B. 2018. Comparative assessment of different herbal galactogoguepreparations on milk production and economics of lactating crossbred cows. J. Pharma. Phyto., 7(5): 2508-2512.

Kumar, S., Mehla, R.K. and Singh, M. 2014. Effect of Shatavari (Asparagus racemosus) on milk production and Immunemodulation in Karan Fries crossbred cows. Indian J. Tradti. Knowl., 13(2): 404-408.

Mishra, A., Niranjan, A., Tiwari, S.K., Prakash, D. and Pushpangadan, S. 2005. Nutraceutical composition of Asparagus racemosus (Shatavari) grown on partially reclaimedsodic soil. J. Medi. Aroma Plant Sci., 27(3): 240248.

Pandey, S.K., Sahay, A., Pandey, R.S., Tripathi, Y.B. 2005. Effect of Asparagus racemosus rhizome (Shatavari) on mammary gland and genital organs of pregnant rat. Phytother. Res., 19: 721-4.

Patel, V.K., Joshi, A., Kalma, R.P., Parmar, S.C., Damor, S.V. and Chaudhary, K.R. 2016. Shatavari (Asparagus racemosus), Jivanti (Leptadenia reticulata) and Methi (Trigonellafoenumgraecum) the herbal galactogogues for ruminants. J. Livest. Sci., 7: 231-237.

Saini, V.P., Choudhary, S., Tanwar, R., Choudhary, S.D., Sirvi, S.P. and Yadav, V.S. 2018. Effect of feeding Shatavari (Asparagus racemosus) root powder on qualitative and quantitative parameter of milk in crossbred cows. Int. J. Curr. Microbiol. App. Sci., 7(8): 3265-3277. 
Sharma, A. 2010. Influence of polyherbalimmunomodulator supplementation on production performance and milk quality of Karanfries cows. Ph.D. thesis, National Dairy Research Institute, Karnal, Haryana, India.

Singh, S.P., Mehla, R.K. and Singh, M. 2012. Plasma hormones, metabolites, milk production, and cholesterol levels in Murrah buffaloes fed with Asparagus racemosusin transition and post partum period. Tropical Anim. Health Prod., 44: 1827-1832.
Thomsen, M. 2007. Shatavari - Asparagus racemosus. w.w.w. Phytomedicine.com.

Veena, N., Arora, S., Singh, R.R.B., Katara, A., Rastogi, S. and Rawa, A.K.S. 2013. Effect of Asparagus racemosus (Shatavari) extract on physicochemical and functional properties of milk and its interaction with milk proteins. $J$. Food Sci. Tech., 52(2): 1176-1181. 
